\title{
The Patenting Dilemma in Mexican Public Universities: the Case of ICAT-UNAM
}

\author{
Vega-González Luis Roberto \\ Instituto de Ciencias Aplicadas y Tecnología, UNAM, Circuito Exterior S/N \\ Ciudad Universitaria, A.P. 70-186, Alcaldía Coyoacán, CP 04510, México D.F., México \\ Tel: 55-5622-8602 ext. 1135 and 1185 E-mail:1rvg@servidor.unam.mx
}

Received: January 4, 2021 Accepted: January 30, 2021 Published: February 24, 2021

doi:10.5296/ber.v11i1.18340

URL: https://doi.org/10.5296/ber.v11i1.18340

\begin{abstract}
Technologies and academic inventions are developed in the daily work of the faculties, centers and research institutes of public universities. Since not all of them have commercial potential we propose that they not necessarily must be subject to patenting, because they can be protected with other intellectual property figures. Although, in many cases the inventions have technical relevance and comply with the legal requirements, they do not have a market focus, therefore they are not susceptible to commercial exploitation, or even they are not oriented to the solution of a specific social problem. This work deals with the dilemma of which academic inventions must be subject to patent in a deep austerity environment. Patenting requires considerable time, financial and human resources and in a context that all type of resources in Mexican public universities are scarce and eventually are further reduced in times of deep austerity, special care must be taken with what is patented. Using the Case Study of an R\&D public institute, in this article we develop a quick method for evaluating whether or not university academic inventions should be patented, using scientific, technological, commercial and financial relevance criteria once the invention complies with legal criteria.
\end{abstract}

Keywords: Academic inventions, Patenting dilemma, Public university

\section{Introduction}

Governments in developing countries fully recognize the importance of Research, Development and Innovation ( $R \& D+i)$ activities. Innovation is understood as the engine of business and economic development, which produces important benefits for companies and important social impacts (Córdoba, Castillo and Castillo, 2018; OCDE, 2012).

If we assume that economic growth depends, among other things, on business innovation and 
that this occurs to some extent from the transfer of technology developed in universities to companies, this would mean that it is necessary to patent university inventions in order to transfer them to society sectors, but this is not so simple, there are many obstacles, starting because some university academics do not want to show and open their inventions to the public. (Link, Rothaermel y Siegel, 2008).

The state intervenes by directing national science and technology systems through general economic development plans and specific science and technology plans. The public policy models of developing countries frequently promote the increase of the number of patents (Piñeiro, Rodríguez and Arzola, 2013).

Thus, the 2014-2018 Development Plan of the Mexican Federal Government and the Special Program for Science, Technology and Innovation (PECiTI, page 36) states that: “... the low percentage of patents granted to nationals $(2.2 \%)$ indicates that it is necessary to reinforce the culture of intellectual property in companies, Higher Education Institutions (IES, from Spanish), research centers and other actors in the system of Science, Technology and Innovation (CTI, from Spanish), with the intention of generating a greater number of patents that can be transferred and exploited." (CONACYT, S / F).

In the regulatory context mentioned previously, the annual average of patents requested by the different economic sectors of the country to the Mexican Institute of Intellectual Property (IMPI), between 2010 and 2018, was approximately 16,068 of which more than 92,168\% were foreign applications in Mexico, generally related to the control of established markets, as is the case of the pharmaceutical and automotive industries, while in some other Latin American countries a slightly higher number of patents are submitted (IMPI, 2018).

On the other side, frequently, the low level of economic development, the low level of GDP growth, the increasing level of unemployment and the increase in poverty, among other economic variables of the country are indirectly attributed to the low number of patents applied and granted.

In response to this challenge, in Mexico, public universities (UP) have assumed the mandate of current Laws and in their development plans they promote the increase of patents for the inventions they produce. May be the reasoning behind is that by increasing the number of patents the local economy will automatically benefit. (Pontaza, 2017; Secretaría de Economía, 2017; Hernández, 2019).

However, it is difficult to find public documents or guidelines that clearly establish what universities and public organizations such as institutes and hospitals in the health, energy and environment sectors, among many other institutions, should do with the patents that are obtained and almost nobody reports the results of their exploitation.

Thus, the patenting programs seem to be in tune with the campaigns and public policies promoted by government leaders, in which they seek to patent more and more (Graue Wiechers, 2017), nevertheless, they do not clearly establish what to do with the patents granted by the authority. Although this should be obvious, but it is not, so it is imperative to establish the objectives, direction and meaning of patenting inventions produced in public 
institutions.

Thus, the aim of this work is to help to respond the following questions: Should Mexican public universities and High Education Institutions seek more patents for non-market oriented academic inventions? In such a case, which of those inventions must be subject to patent?

In order to answer, it is imperative to know that there are some restrictions. Among others, we have to recognize that in the public universities of the countries that make up the Latin American region, as well as those of other third world countries, the economic resources applied to $R \& D$ are scarce. Even more, in the case of Mexico, with the austerity program imposed in 2018 by the government of the republic for the scientific and research system, today, the situation has become more complicated. (Laurell, 2018; Lazcano, 2019; Woldenberg, 2019). Furthermore, according to Vega and Hernández (2017), obtaining a patent in Mexico is an expensive process.

Based in a Case Study, the objective of this descriptive empirical research work is to develop a quick and simple method to determine to patent or not the academic inventions that are developed in the faculties, institutes and R\&D centers of public universities.

\section{Theoretical Framework}

\subsection{Academic Inventions versus Market Oriented Inventions}

It is important to note that there are some important operative differences between the R\&D university institutions of developed countries and those of developing countries. The first is the source of the operations funding. A public R\&D university institution in a developed country receives a part of its financing from the state, but it also receives economic resources, sometimes more than $50 \%$, from companies and private institutions via contracted technology development. In contrast, in similar institutions in developing countries, more than $90 \%$ of their financing comes from the state.

This situation clearly influences the type of inventions that are obtained as a result of the projects developed. In both cases, the institutions primarily develop technology and inventions as a result of their experimental research and teaching projects.

We will call these academic inventions and they are generally not market oriented, which makes their technology transfer very difficult.

The main difference is that practically all the technology developed with firms financing is usually market-oriented. For this reason, institutions in developed countries produce more market-oriented inventions. While in the public university institutions of developing countries the opposite occurs.

\subsection{R\&D between Firms and Universities in Developed Countries}

In the United States increased efforts by universities to foster the commercialization of technological innovations erodes the singular position of institutions of higher learning. Based on past performance, there is little reason to expect that a substantial reallocation of faculty effort towards commercially oriented $R \& D$ will generate appreciable net revenues for 
other than a select number of universities (Feller, 1990).

Veugelers \& Cassiman (2005) points out that large firms and firms in the USA chemical and pharmaceutical industry are more likely to be actively involved in industry science links. Cooperating with universities is complementary to other innovation activities such as performing own R\&D, sourcing public information and cooperating with other partners.

Linking scientific knowledge is especially important for firms innovating in the fast developing technologies like biotechnology, information technology and new materials. On average the evidence suggests a positive effect of knowledge transfers from science to industry. Although, universities have traditionally been centers of basic research, they increasingly engage in the cooperative conduction of applied research.

Similar approaches occur in Europe, Roesler \& Broecker (2017) mention, that the role of universities in a network of subsidized R\&D collaboration for the biotechnology-industry in Germany, is as central knowledge driving knowledge network evolution and dominate the network as partners in many $R \& D$ projects. In this kind of networks, firms' competitiveness emerges from the capability to exploit, integrate, and recombine existing knowledge in order to produce new knowledge more efficiently than their competitors (Kogut and Zander 1992; Grant, 1996; cited by Roesler \& Broecker, 2017).

Knowledge acquisition and generation are thereby increasingly the result of collaborative research and development (R\&D) activities. In this environment, universities engage in a wide range of activities. First and foremost, they educate students and thereby upgrade human capital. Equally important is the role of universities as knowledge accumulators and generators.

\subsection{Technology Transfer}

Carlsson \& Fridh, (2002) states that following the Bayh-Dole Act of 1980, many U.S. universities have set up offices of technology transfer (OTT) in order to facilitate commercialization of research results. Technology transfer from universities to the commercial sector needs to be understood in its broader context. It is not simply a matter of maximizing income for the universities, even though in a few cases quite substantial income is generated. It is rather a matter of finding the proper balance between the basic functions of teaching and research within the universities on the one hand and providing service to the wider community. The primary purpose of a technology transfer program is for the university to assist its researchers in disseminating research results for the public good.

There are several stages in the technology transfer process, each associated with its own outcome: invention disclosure, patent application, patent issued, license sold, license income and/or business start-up. As a rule, only half of the invention disclosures result in patent applications; half of the applications result in patents; only a third of patents are licensed, and only a handful $(10-20 \%)$ of licenses yield substantial income.

Lockett, Wright \& Franklin (2003) propose that universities may seek to transfer technology from the public to the private sector, and therefore capture the benefits of commercialization, 
through a number of different mechanisms. One of them is the option of using technology-based spin-out companies. The more successful universities possess a greater expertise and networks that may be important in fostering spin-out companies.

The commercialization of university-based technology has become a prominent issue in the policy arena in both the U.S. and the U.K. The spinning-out of inventions into separate companies represents a potentially important but as yet under-exploited option. In the U.S., the transfer of technology from the public to the private sector is increasingly regarded as playing a significant role in new business starts, growth of existing businesses, and new job creation (Siegel et al., 1999; cited by Lockett, Wright \& Franklin, 2003).

\subsection{Patents at Universities}

Wallmark (1997) Mentions that demands for increased relevance of university research to society needs have stimulated interest in inventions at universities and raised questions about the proper balance between basic and applied research. Hence at the Chalmers University of Technology about $50 \%$ of the university patents have been used for start-up of new spin-off companies and for supporting their growth, while the other $50 \%$ have gone to established non-spin-off industry. The economic value of the patents has been estimated on the basis of employment (turnover) in the spin-off companies.

For Kamariah, Wan Zaidi and Izaidin (2011), universities do differ on which inventions need to be patented and which route to go for their commercialization. Universities that practice very highly selective procedures would only patent an invention after a very thorough market analysis. But there are universities that practiced low selective procedures; as such, they file for patent as long as the invention fulfils an expectation of potential value. Decisions on which route to commercialize are sought after the patent filings.

It is important to note that Universities as Caltech struggle to make patents pay for doing so they license their patents to firms. In 2008, Caltech exclusively licensed more than 50 patents, to a subsidiary of Intellectual Ventures, a broker company that has stockpiled 40,000 patents from which it collects US $\$ 3$ billion in licensing income. The firm sometimes uses its patents to sue other companies for infringement, yet it rarely develops the inventions described by its intellectual property. But in the push to get academic research out of the ivory tower - and to make money - university technology-transfer offices are becoming less choosy about their partners (Ledford, 2013).

Universities often say that the goal of licensing patents is to stimulate the economy by translating publicly funded research into companies and products. But the unstated aim is to make money to fund more research and the technology-transfer.

Over the past few years, many countries have taken measures to promote knowledge and technology transfer between universities and industry. In the UK, such an activity is widely regarded as a Third-Stream activity.

Along with such an emphasis on Third-Stream activities goes a need for developing indicators that effectively capture the value generated by such activities, particularly for 
accountability purposes. As public funds are increasingly being dedicated to develop knowledge and technology transfer functions in universities, the UK Government is increasingly requiring measures to demonstrate some form of return on its investment. In their research, Meyer \& Tang (2007) found that unsurprisingly, licensing is an important measure of patent value, although simple counts of patent applications may be open to easy manipulation.

\subsection{The Value Increases from Inventions to Patents}

Another important issue is the value of patents. Guellec \& Van Pottelsberghe (2000), cited by Meyer \& Tang (2007) presented a gradual value scale from inventions to exploited patents. See Figure 1

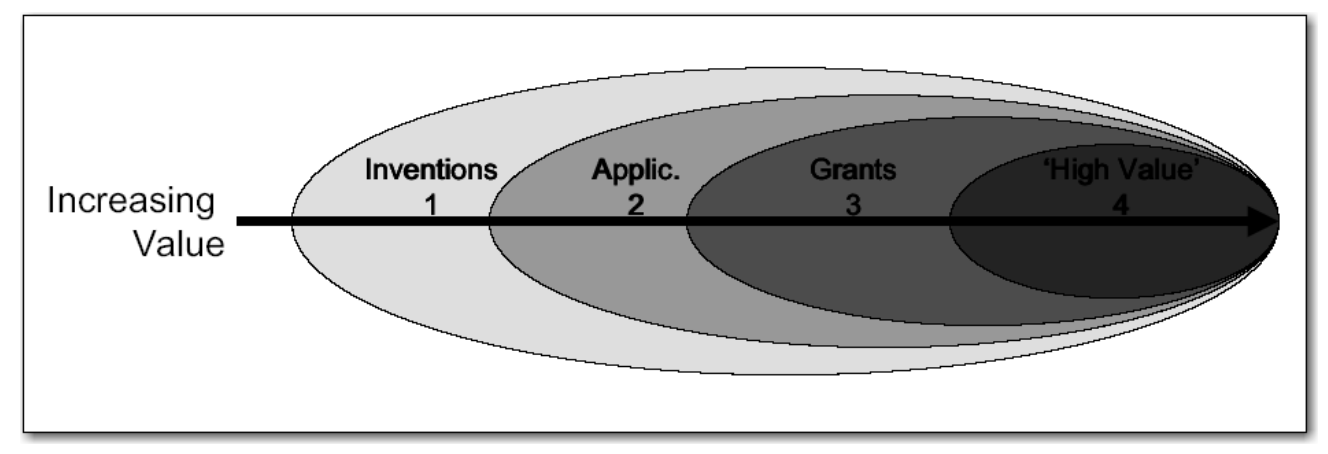

Figure 1. The value of inventions and the value of patents

Source: Adopted from Guellec \& Van Pottelsberghe (2000) cited by Meyer \& Tang (2007)

The value increases from left to right. The authors propose that inventions are the items of lower value. Increase their value when they transform in applied technology, right away patent grants for this technology have a higher value than technology without intellectual property. Finally, the potential high-value patents are those licensed with high income potential. The authors also mention that high numbers of citation, renewal rates and family size also imply extra value.

\subsection{Economic Growth}

Thinking that the economic growth of a country depends on the number of patents filed and granted from the competent authority is a simplistic thought that is not entirely correct since macroeconomic processes are very complex; in other words, they depend on a huge number of variables and have an intense dynamic behavior. Besides, sometimes it takes many years to observe the appearance of notable changes in the macroeconomic system, given the change in various economic variables. Among others, some variables that have a cross-cutting effect on economic growth in most countries are temporality, the ability to develop or adopt technology, and their own level of development.

Adam Smith and other economists and philosophers of the 18th century posited that the productivity of the labor force was the variable that helped to create wealth. They claimed 
that technological change was the primary source of growth and that the incremental rate of technological change was the main cause of differences in income, well-being and wealth between countries.

Later, at the end of the 19th century, in the middle of the industrial revolution, the economic growth of developed countries was favored by the emergence of General Purpose Technologies (GPT) for the manufacture of capital goods such as large turbines, pumps, transformers, industrial transformation plants, process and manufacturing equipment, as well as the emergence of firms specialized in solving specific technological problems (Rosenberg, 2010), the transfer and adoption of technologies (Rosenberg, 2010) and the relocation of industries, among many other factors.

In other words, wealth and economic growth occurred with the development of breakthrough inventions and innovations that allowed the manufacture and use of capital goods that when installed in manufacturing and / or process plants, boosted the production of consumer products. Additionally, breakthrough innovations caused currents of incremental innovations that generated large waves of economic growth.

At present, in practically all developing countries many of these principles are still in force since to promote the growth of economic variables it is not only necessary to carry out applied science and technological development to obtain inventions that solve problems for society and patenting them, but also creating companies and industries or expanding their production lines, based on new patents. In a recent econometric study carried out between 2004 and 2012 in thirty countries, it is concluded that the creation of companies is currently one of the main determinants of economic development (Loukil, 2019).

On the other hand, Osiobe (2019) proposes that economic growth not only depends on the creation of companies, but that its natural complement is the formal and informal training of human capital to develop productive well-being through work, skills and knowledge of the human beings. Many other economic variables influence to a greater or lesser degree the economic growth of a country. Viettha (2019) points out that inflation and exchange rates act as mediating variables of economic growth through the stock market.

\subsection{Patents and Technology Transfer in Latin America}

Calderón-Martínez (2014) points out that in the case of Latin America, universities are still in a phase of opening up to collaboration with the productive sector. Viana, Jabour, Ramirez and da Cruz (2018) agree with this assertion, because they mention that in the case of Brazil, the results of academic research are not efficiently absorbed by industries and consequently only an insignificant percentage of patents reach the market. They also mention that innovation in Brazil is in its infancy compared to the world average.

However, they have been working hard to implement public policies for high-tech sectors, such as biotechnology (Caffé de Oliveira and Biondi, 2013).

On the other hand, Schmal, López and Cabrales (2006), cited by Zaldívar and O'Connor (2012), mention that, in the case of Chile, both the University of Concepción and the 
Universidad Técnica Federico Santa María, own around 50\%. of university patents, although only a percentage of $5 \%$ is granted, but none is generating revenue; that is, none was transferred for commercial exploitation.

Another case is Colombia, in which the National University of Colombia holds more than half of the patents granted in the country between 1994 and 2004. Of the twenty patents applied for, only three were granted and only one generates income.

In Cuba, between 1980 and 2000, 2179 applications were submitted, 724 of them were granted, and only $20.2 \%$ were exploited.

In the case of Mexico, patents granted to universities have had little impact on regional development, which may be linked to factors such as low absorption capacity by industry, differences in research results and the needs of the industry, as well as the weakness of existing incentives for the protection of intellectual property. According to Estrada (2007), of all the patents generated by Mexican universities, more than $90 \%$ have not been and will not be transferred to the productive sector or society, as they have not been designed for Mexican organizations to produce, and introduce them in the market in the form of technological innovations.

Finally, on the side of regulations, Díaz, Giraldez, Armas and Rodríguez, (2013), mention that, in most Latin American countries, inventions must meet the same patentability criteria established by Mexican Laws.

The situation in Latin American countries is in stark contrast to what is happening in developed countries. In this regard, Meyer, Krahmer and Schmoch, (1998) mention that, in countries such as Germany, a patent only makes sense in a scientific institution if it is interested in the commercial exploitation of a new discovery and seeks to achieve a collaboration with a business partner.

\section{The Research Method: A Case Study}

The applied research method used in this work was the case study. Martínez (2006) mentions that this research method allows the inductive analysis of the qualitative data that is recovered from the case description. This type of research presents some uncertainty since quantitative methods are not applied. However, for Aguilera (2011), this facet of scientific knowledge requires working with analogies, inferences, presuppositions and conclusions, in order to logically structure both the definition and the foundation of the problems.

The above implies having a specific conception of reality. In this case and from the perspective of scientific knowledge, the problems that are studied and analyzed are human elaborations, they are social constructions elaborated in base to certain particular conceptions of reality.

For Yin (1989, cited by Martínez, 2006), the case study method is a valuable research tool, whose greatest strength lies in the fact that it measures and records the behavior of the people involved in the phenomenon studied, while quantitative methods only focus on verbal information obtained through questionnaire surveys. 
For Meyer (2001) a case study consists of detailed investigation of one or more organizations, or groups within organizations, with a view to providing an analysis of the context and processes involved in the phenomenon under study. For Gummesson (1988:76, cited by Meyer, 2001) an important advantage of case study research is the opportunity for a holistic view of the process: "The detailed observations entailed in the case study method enable us to study many different aspects, examine them in relation to each other, view the process within its total environment."

Tellis (1997) considers that a case study can be seen to satisfy the three tenets of the qualitative method: describing, understanding, and explaining. Meanwhile, Ebneyamini \& Reza (2018), indicate that a case study is an empirical inquiry that investigates a contemporary phenomenon within its real-life context, especially when the boundaries between the object of study and context are not clearly evident. Yin (2003). It is one of the most powerful methods used by researchers to realize both practical and theoretical aims. Researchers in technology and innovation management need to use more field-based research methods.

\section{The Case of Patenting at ICAT-UNAM}

This work is an empirical research, based on the practice of technological project management carried out for several decades, and on the observation and documentation of patenting activities in various entities of the Universidad Nacional Autónoma de México (UNAM), the oldest Mexican public university. In particular, direct experience in the management of the Intellectual Property Unit of the current Institute of Applied Sciences and Technology of UNAM has been obtained over the last twenty years.

The dynamics of patenting in Mexico are very different from what happens in developed countries; in addition, the phenomenon has different behaviors depending on the region of the country studied; that is, what happens in Mexico City and in the center of the country is different from what happens in the northwest in cities like Monterrey Nuevo Leon, and Saltillo Coahuila or in the Southeast including states like Yucatan and Chiapas.

On the other hand, there is no large sample of data, so it is only possible to glimpse the behavior and trajectories of the associated phenomena. Universities and higher education institutions participate with about 5 and $10 \%$ of the total patent applications filed and granted by the authority annually.

\subsection{Industrial Property Law in Mexico}

In Mexico, Intellectual Property rights are protected by two institutions; The copyright of literary, theatrical, paintings, artistic works in general and computer programs and databases are protected by the National Institute of Author's Rights (INDAUTOR), while Industrial Property rights are protected by the Mexican Institute of Industrial Property (IMPI). Patents are the most important Intellectual Property titles, from the point of view of legal protection against infringements.

The duration of patent rights established in international agreements is 20 years from the date 
of application. This figure applies to the majority of the member countries of the United Nations (UN) and the World Trade Organization (World Trade Organization), as well as for the 140 countries that are part of the Patent Cooperation Treaty (PCT).

The monopoly right obtained from the grant of a patent means that no one else can exploit the patented invention without the consent of the owner. Even in the event that someone tried to use the monopolized knowledge and even if they did not know anything about the existence of the patent, they could fall into an infringement. This is based on the legal concept that ignorance of the law does not exempt you from complying with it.

With the patent title, the state grants the owner, individual or legal entity, the exploitation, production or use exclusively or through a third party under license of their invention with certain limitations such as territoriality and temporality.

In other words, the patent is granted only for the country where it was applied for and is subject to its legal provisions. In Mexico, a patent granted by IMPI is valid throughout the Mexican territory and its regulations and filing rules are governed by the provisions of the Industrial Property Law (IPL).

The IPL was issued in Mexico by the Chamber of Deputies (2018), published in the Official Gazette of the Federation (DOF) on June 27, 1991 and its latest amendment was published in the DOF on May 18, 2018 and Agreement of September 2019.

The IPL mentions in its Article 15 that any human creation that allows transforming matter or energy that exists in nature is considered an invention, for use by man and satisfy his specific needs.

IPL Article 16 establishes that the specific conditions for inventions to be patentable are: (a) inventions that are new, (b) must be the result of an inventive step, and (c) must be capable of industrial application.

The inventions that are patentable according to IPL Article 45-I are: products, articles, chemical compounds or mixtures. Article 45-II includes processes, procedures or methods and Article 45-III includes machines or apparatus.

On the other hand, the Law establishes that the following are not patentable: I.- Essentially biological processes for the production, reproduction and propagation of plants and animals; II.- The biological and genetic material as they are found in nature; III.- The animal races; IV.- The human body and the living parts that compose it, and V.- Vegetable varieties.

With the recent advent of genomic engineering for the modification of plant varieties, the IPL has included a new Law of Plant Varieties.

In recent years the international patent system has grown impressively. In 2018 alone, innovators around the world filed 3.3 million patent applications (WIPO, 2019), of which China alone received 1.5 million patent applications. Patents granted worldwide that same year were 1.42 million. The direct consequence is that it is increasingly difficult to meet the first criterion for patenting; that is, it is increasingly difficult for inventions to meet the 
universal novelty criterion. This is directly associated with the identification of the claims or what the inventor claims as his own in the patent application.

\subsection{Patent Costs in Mexico}

Obtaining an invention patent entails, a series of associated costs. Many of them vary depending on the country in which you want to patent, the nature of the invention and the complexity of the technology. Costs vary depending on the country where the patent is filed, the nature of the invention and the complexity of the technology. Likewise, the exchange rates of the currency of the country in which the patent is filed must be considered.

Among others we have the following costs:

- Search for prior art, carried out by an expert in the field.

- Specialist fees, hiring of experts, specialist lawyers or, when applicable, patent agents for drafting.

- Translation costs

- National and / or international processing of the application.

- Payment of official filing fees before the national patent offices. This cost varies depending on each country.

- Payment of expert opinions for the performance of the exam (s) carried out by each Patent Office (the so-called "Substantive Examination").

- Costs associated with the legal response to oppositions that the application may suffer in each patent office where it is entered

- Payment of maintenance fees and expenses associated with the observance of rights, according to the respective legislation.

- Process management costs, including management office staff time, investigator time, administrative processes.

Therefore, the costs incurred to obtain a patent are not only the government rates, but it is essential to prepare an estimated budget, when defining the protection strategy of a new invention.

According to Vega-González and Hernández (2018, p. 10), patenting costs in a public university are in the order of \$3,500.00 USD for patents in Mexico and the process takes an average of 5 years. Patents in the United States of America cost an average of \$11,250.00 US dollars and require between two and a half to three years on average to be granted.

The national phase of a patent submitted via the Patent Cooperation Treaty (PCT) costs approximately US $\$ 8,500.00$ and requires an average of 30 months before entering the international phase. To this cost we must add the cost of the national phase, which will depend on each country in which the patent is requested. Since the costs of patenting are significant, when you do not have your own resources for this purpose, it is essential to seek 
external sources of financing.

\subsection{The Sources of Funding}

The financing of public university patents always has depended on the institution year budget. Until a few years ago, it was possible to count with economic resources coming from government institutions dedicated to the promotion of science and technology.

Back in 2008, the Directorate of Liaison and Intellectual Property of the Institute of Science and Technology of the Federal District (ICyTDF), now Mexico City (CdMx), promoted a patent program for institutions, companies and individual inventors to present their inventions through an annual call. The winners would receive a cash prize of $\$ 50,000.00 \mathrm{MN}$ (approximately $\$ 2,500.00$ USD) and would be paid the costs of drafting, filing the patent with the IMPI and paying fees. Soon the call was established biannually and in each of them an average number of ten inventions developed in the CdMx was awarded.

The aforementioned Institute disappeared in 2012, so throughout its life, approximately 100 inventions from university institutions, companies and private inventors in Mexico City were awarded and patented. Until the closure of the institute, it was not reported that there had been any transfer of productive technology that had produced interesting economic results.

Subsequently, in 2010, a new institution was created within UNAM, the Coordination of Research and Development (CID). With its own budgetary resources, allocated by the Rector's Office they used the prize idea created by the ICYTDF, to reward inventors to motivate patenting.

Currently, the main funding sources for technology development projects are the National Council of Science and Technology (CONACYT) part of the federal government, and the similar organism at the local Mexico City government level, the Ministry of Science, Technology and Innovation (SECTEI). Both institutions also finance the drafting and fees for patent applications made for inventions developed by both government and public sector institutions.

\subsection{Uses of a University Patent}

Patents are property titles of knowledge, which are understood as intangible assets; however, like tangible properties such as real estate, the owner can take advantage or usufruct from them. Patents can be sold, rented, given away, or given for free use to a third party, and so on. Figure 2 shows the various uses that can be given to a patent. 


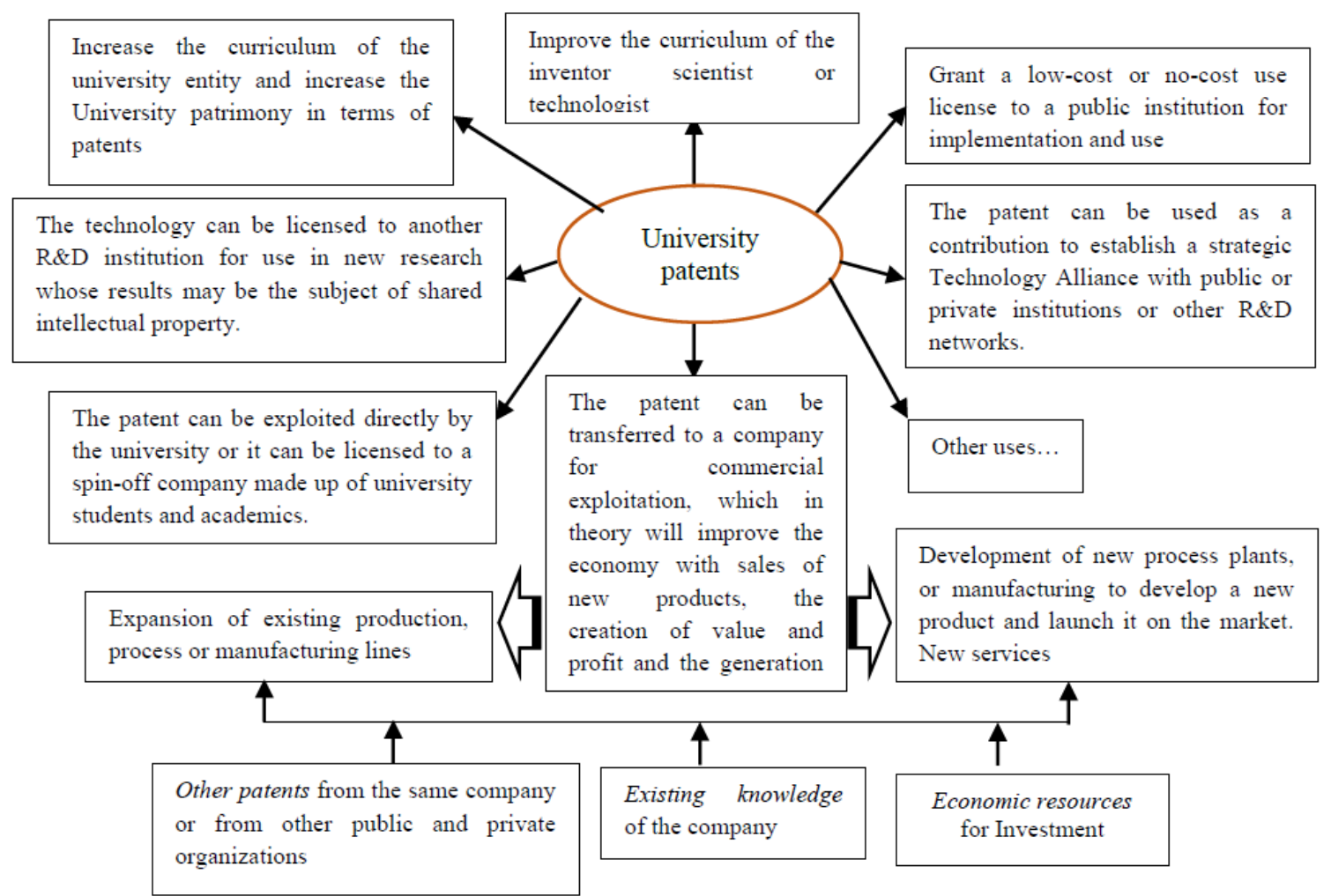

Figure 2. Possible uses of a patent

Experience shows that in the case of public universities, the patenting of the inventions of their academics does not automatically and directly promote the improvement of the national economy, nor the job creation and social welfare.

In most cases, exploiting a patent requires strong investments to install a new production process, a new manufacturing plant or modify existing ones. Firms also have to invest in marketing campaigns, market launch, implement sales force, to open a new market or compete for a portion of it.

It is natural that companies or individuals who have plenty financial resources to carry out these operations can usually develop their own inventions and patent them. In many cases they are foreign companies which are granted 80 or $90 \%$ of patents in Mexico.

For many years the academic inventions patents granted by authority to public institutions were used for evaluation purposes of the research inventors and job promotions, even they haven't been licensed or been exploited. This situation produced an increasing demand to technology transfer offices for patenting academic inventions with no market orientation. The dilemma becomes evident when inventors request the filing of patents but there are not enough economical resources to pay for them and the expectance for incomes from its commercial exploitation is practically null. 


\section{The Evaluation Method}

To evaluate which academic inventions be patented to solve the dilemma we propose the relevance-compliance method described below.

\subsection{Fundamental Relevance Criteria}

The decision of whether or not to patent must be made through the determination of the relevance and the compliance with the Law requirements of the invention.

In the first place, it must be established that for a university invention not only to remain in a file of the entities or legal offices, or in the curriculum of the academic inventor, it is desirable and on some occasions imperative, that the invention actually reaches the society; that is, it must contribute to some extent to the solution of a problem or need for it.

Thus, Figure 3 sets out the fundamental criteria of relevance with reference to the central objective of the patent. These criteria are as follows:

(a) Social criterion: the invention must be disseminated in society to promote its well-being and progress. This can be done through the granting of user licenses for public institutions or social enterprises, at no cost, or through dissemination and application of technology carried out by members of the university itself, such as dental and medical clinics, institutions of charity, social support days, schools, cultural centers, among many others.

(b) Economic criterion: the patented technology must reach the market to be exploited commercially through its technology transfer to a public or private organization.

(c) Technological Criterion: it must have a high scientific-technological quality and be collectively evaluated by the heads of the academic groups of the institution and the authorities that are part of the Institutional Patent Committee.

The invention may meet all or only one of the fundamental relevance criteria from the point of view of its application. The second main aspect to take in account is that the source of the economic resources required to carry out the patenting project had been budgeted previously or another external source have been identified.

It is essential that the university has the resources and that they be available as required since the beginning of the project or that there is a budget program so money be available as necessary when carrying out the process. The economic resources could come from the university budget or from government institutions that promote and support $\mathrm{R} \& \mathrm{D}$, from companies or from other sources. 


\section{MInstitute Macrothink}

Technological, the invention has been the result of $R \& D$ projects and human resources training developed by the institution and not financed extemally. At the same time, it must have a high scientific-technological quality, collectively evaluated by the heads of the academic groups of the institution and the authorities that are part of the Institutional Patent Committee. The technological product must be perfectly aligned with the institutional objectives and the critical competencies that must be developed to fulfill the organizational mission and vision. In this case, it does not matter that there is no interested company or extemal institution, the interest in patenting lies with the same institution. Patenting these inventions is an institutional strategy.

Economic or Commercial, the
invention is a technological
product designed for its
introduction and exploitation in
the market. There must be
interested companies and a well-
identified and defined market.
The best case is when a company
interested in its licensing has
already been detected

Figure 3. Fundamental Relevance Criteria

Social, the invention is a technological product that can clearly be used by a public institution of health, edvcation, security, research or social welfare, to improve the efficiency of its operations, with applications in water, energy, environment, sustainability, among others. Interested non-profit governmental institutions must be well identified. The best case is when the development of the technology was requested and financed by an institution interested in its licensing.

\subsection{Secondary Logistics Requirements}

For patenting process feasibility, it is necessary verify that the operational variables be under control; in other words, it will be necessary to identify if there is administrative and management capacity, and if there is an efficient logistical support system. It must be defined whether the process will be carried out by a contracted external patent office, or by patent drafters contracted and coordinated by the staff of the Technology Transfer Office.

Using information from technological intelligence, the inventor, the institution's authorities, the heads of technology transfer offices, and other stakeholders should discuss and answer questions such as: is it a good time to exploit the technology? Is it worth the investment and effort? Do we have market opportunities? Are there possibilities to achieve social impact?

In many public universities this can be handled by a technology transfer office in which specialized personnel work in the application, obtaining and administration of patents, as well as in the development of intellectual property strategies.

\section{Results: Method of Relevance-compliance to Evaluate Patenting}

\subsection{Method for Evaluating whether to Patent}

Figure 4 shows the integrated method developed for the evaluation of the patenting of an academic university invention. 


\begin{tabular}{|l|l|l|}
\hline & $\begin{array}{l}\text { Does the invention meet at least one of the fundamental criteria? In other } \\
\text { words, is it an invention with a clear economic, social or technological } \\
\text { objective? }\end{array}$ \\
\cline { 2 - 2 } & $\begin{array}{l}\text { Does the institution have the financial resources to patent? They're } \\
\text { available? or is there a budgeted program to dispose of them? }\end{array}$ \\
\hline \hline
\end{tabular}

Figure 4. Patent evaluation method

Relevance will be approved for the invention to be patented when at least one of the fundamental criteria referring to the primary objective be met. It is imperative to identify if the primary objective is social, economic or technological. In addition, the necessary financial resources and the required information must be available depending on the primary objective and the type of patent to be obtained.

It is suggested that to define whether the invention meets the fundamental relevance criteria, the following interested members of the institution be interviewed: (a) the inventor, (b) the staff of the technology management or technology transfer office, (c) the institutional authorities, the director, department heads, administrative secretariat and other possible interested parties. In case of doubt, members of at least three other university institutions who carry out tasks close to or similar to those of the institution can also be consulted.

\subsection{Detailed Analysis of Fundamental Relevance Criteria}

Figure 5 shows the suggested block diagram to perform the analysis of the fundamental relevance criteria referring to the primary objective of the patent.

The intention of the questioning in the first and second columns is to discard those inventions that only have the purpose of increasing or enriching the curriculum of the inventors or increasing the prestige and the number of institutional patents. In those cases, the institution should not get involved and the patent application will have to be made with the inventor's own resources. In such a case it is the end of the institutional process.

The third, fourth and fifth columns question whether the approach of the invention is 
technological, economic or social, clarifying aspects such as the quality of the technology, its use, if there is strategic interest or, what is the sector of society that will be benefited, and in what way.

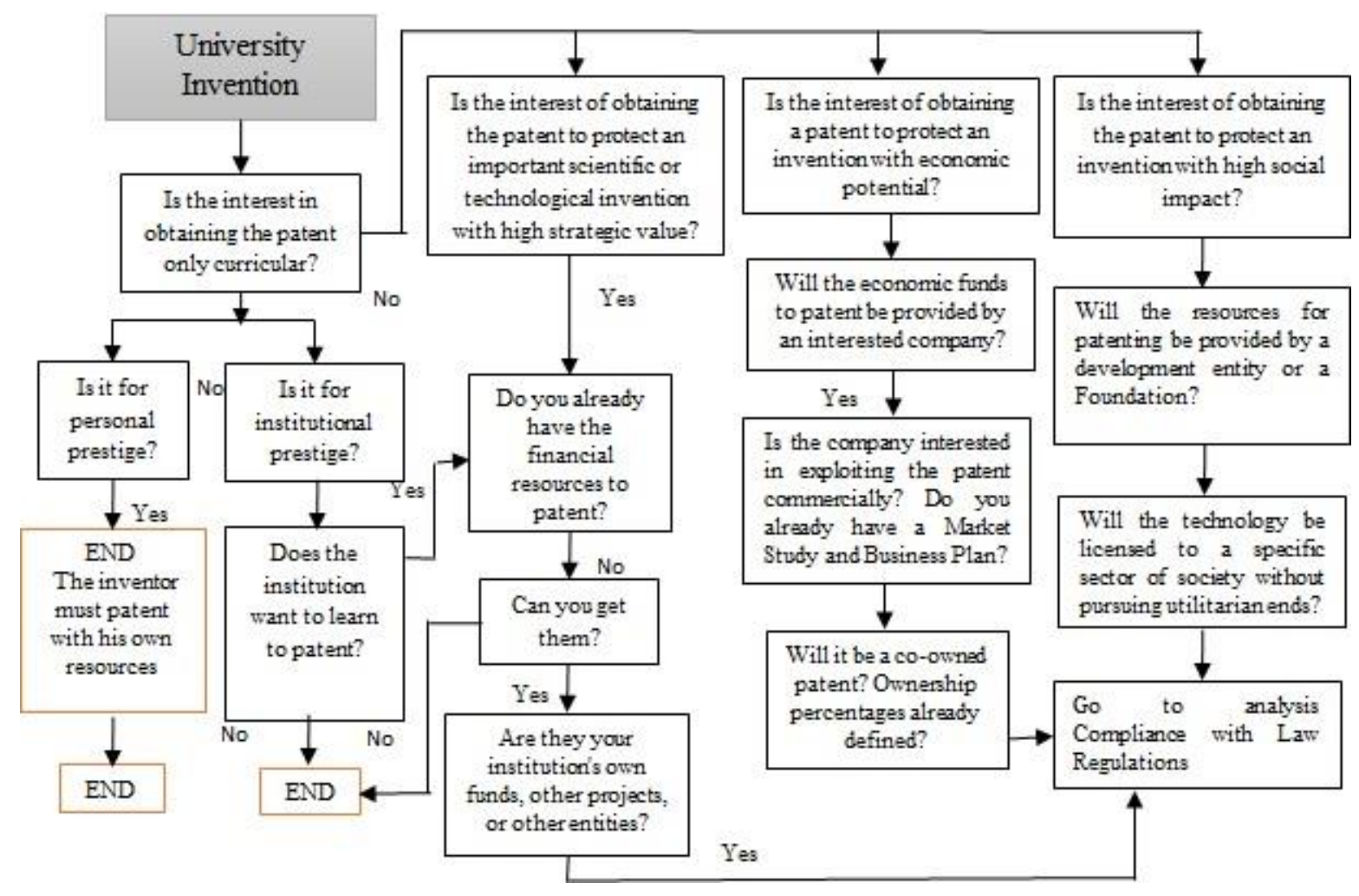

Figure 5. Diagram for analysis of fundamental relevance criteria

\section{Discussion}

Within the theoretical framework of this work, we stated that not all patent applications submitted to the patent offices of Latin American countries are granted and not all granted patents are exploited. It appears to be a double funnel; that is, only a small percentage of the patents applied for will be granted and experience shows that only a small percentage of the patents obtained will be transferred to the productive sector.

In particular, at the Institute of Applied Sciences and Technology (ICAT) of the UNAM, the expectance is that probably a percentage of between 1 to $2 \%$ of the patents applied for will be transferred. However, a higher percentage (5 to 10\%) of inventions protected with other intellectual property figures as utility or design models have been licensed at no cost to social health or safety, environmental or energy institutions, among others. As we mentioned previously, it seems that a very similar situation occurs in other public universities both in Mexico and in Latin America.

Due to the significant costs and the time required in the patenting processes, public universities use the resources of the extraordinary income obtained by carrying out consulting projects, technical assistance, services or technological development on request, to carry out 
patent projects for those inventions that meet the relevance criteria discussed in the previous section. For this reason, government support is very important to carry out technological development projects. Within the budget of these projects it is possible to include the costs of drafting and applying for patents for the resulting technologies.

In this sense, Fuentes and Ferrada (2016) consider that government instruments to support $\mathrm{R} \& \mathrm{D}$ become a meaningful variable in the innovation process. The effect of public financing is positive and not only generates benefits in the business innovation process, but also in the patenting processes of public institutions.

This work does not pretend to be normative, but to highlight and point out that the conditions of public universities are different from those of private universities. Given that in Latin America the percentage of technology transfers is very low, the public university has to focus on very finished and mature technologies with Technology Readiness Level (TRL) of 5 or 6 to scale them so that they have a greater probability of going to the market, and / or on inventions than from origin are shaped to produce a high social impact.

The issue is not just investing resources in the most efficient way, but rather that the effects of inventions reach society as soon as possible and begin to contribute to production chains and at the same time real and alternative mechanisms for protection and technology transfer be established.

\section{Conclusion}

The objective set for this descriptive empirical research work was to develop and present a rapid method that helps to make the decision to patent or not academic inventions in the R\&D institutions of UNAM, which is the oldest public university in Mexico.

The method obtained consists of two parts, the first is the determination of relevance and the second is the determination of compliance with the requirements of the Law for the granting of inventions. This method can also be applied to decide whether to patent inventions made by faculties, institutes and R\&D centers of other public universities in the country or similar institutions in other developing countries.

The first part of the method is carried out by combining the identification of the relevance criterion and the verification of the economic resources availability. If the invention meets these two criteria, then the relevant information and secondary logistics criteria must be compiled and obtained. For decision making it is also convenient to have a study of technological intelligence referred to the invention under evaluation.

The second part of the method is to determine the compliance with the Industrial Property Law requirements for granting patents. Carrying out the evaluation method presented implies acting with institutional responsibility in the exercise of the economic resources that the federal government confers on the university.

The academics and researchers of the university entities have freedom of investigation; that is, they can often conduct research out of curiosity and produce technological developments with the objective of supporting their own basic research. However, more and more 
academics propose lines of applied research and development whose results are aimed to solve any problem or demand of the different economic sectors that make up society. In developing countries, resources are scarce and universities have many operating costs so that, although institutional development plans indicate that it is important to patent, institutions must be responsible in making optimal decisions involving the use of human, time, and financial resources. For this reason, it is so important to decide which inventions are appropriate to patent and which are not.

There are no resources to patent just for patenting. To avoid this, all inventions must undergo the respective evaluation, using the proposed relevance-compliance method, in order to rationalize and support the process, with the ultimate aim of improving the possibilities of their transfer to society.

As a result of this process, it will be justified why only technologies with a high commercial, technological or social impact profile will be patented. Although it seems to be an obvious or simple thing, it is not, because normally most academics want to patent their inventions for curricular reasons, even if they do not meet the described profile.

It is also important to mention that when developing the intellectual protection strategy, there are alternative protection possibilities; for example, obtaining utility models (UM), together with a good number of other titles or certificates such as industrial designs and copyrights, among others.

The state only grants ten years to exploit a utility model, but its cost is much lower and the time for its grant can be reduced to half the time of a patent. Devices, software, machines, systems, and various technologies that are protected with UM's, can reach between seven to 8 years of exploitation, a time very similar to that of the patent, with the advantage that they could be obtained in the middle of the life cycle of the technology.

Nevertheless, patents are still very suitable property titles to protect high-level technologies (Hi-Tech) on chemical, biological processes, pharmacy and genomic medicine, among others. However, it is essential that the inventor and the assignee in title are convinced of its potential for economic and social exploitation and of its high-tech quality that will confer universal novelty.

In the ICAT Industrial Property Unit, the method proposed in this article has been used in recent years, as a result, some inventions with high potential for patent have been selected and filed while other academic groups considered the use of industrial models to protect their inventions. One of the main benefits of the application of this evaluation method is the awareness of the academic R\&D staff regarding the responsible use of resources.

\section{References}

Aguilera, H. R. M. (2011). Identidad y diferenciación entre método y metodología. Estudios Políticos núm. 28 Centro de Estudios Políticos. Universidad Nacional Autónoma de México, Facultad de Ciencias Políticas y Sociales. pp. 81-103.

https://doi.org/10.1016/S0185-1616(13)71440-9 


\section{Macrothink}

Business and Economic Research ISSN 2162-4860 2021, Vol. 11, No. 1

Caffé de Oliveira, D., \& Biondi, I. (2013). Analysis on Sub-national level of Biotechnology Development Policy in Brazil: Technological Innovation and human health in the state of Bahía. Journal of technology management \& innovation, 8(suppl.1), 26-38.

https://doi.org/10.4067/S0718-27242013000300032

Calderón-Martínez, G., (2014). Patentes en Instituciones de Educación Superior en México. Revista de la Educación Superior, 43(170), 37-56. https://doi.org/10.1016/j.resu.2014.06.001

CONACYT, (S/F). Programa Especial de Ciencia Tecnología e Innovación (PECiTI). Recuperado de: [Online] Available:

http://www.siicyt.gob.mx/index.php/normatividad/nacional/programa-especial-de-ciencia-tec nologia-e-innovacion-peciti

Córdoba, Z. E., Castillo, T, J., \& Castillo, Q. N. (2018). Creatividad e Innovación: Motores del Desarrollo empresarial. Lámpsakos, 19, 55-65. https://doi.org/10.21501/21454086.2663

Díaz, P. M., Giraldez, R. R., Armas, P. D., \& Rodríguez F. R. J. (2013). Revista. Avances, 15(4), 426-429.

Ebneyamini, S., \& Reza M. S. M., (2018). Toward Developing a Framework for Conducting Case Study Research. International Journal of Qualitative Methods, 17(1), 1-11.

https://doi.org/10.1177/1609406918817954

Estrada, O. S. (2007). El impulso a la innovación e invención tecnológica en las empresas y las universidades mexicanas para fortalecer la autonomía de la economía del país. [Online] Available: http://www.senado.gob.mx/comisiones/LX/cyt/content/seminarios/universitario/Se rgioEstradaOrihuela.pdf

Fuentes S. R., \& Ferrada, R. S. (2016). Innovación Tecnológica en Empresas Chilenas: Un Estudio Empírico Basado en Patentes. Journal of technology management \& innovation, 11(4), 56-64. https://doi.org/10.4067/S0718-27242016000400008

Graue, W., E., (2017). Plan de Desarrollo Institucional 2014-2019. Universidad Nacional Autónoma de México. [Online] Available:

http://www.rector.unam.mx/doctos/PDI-2015-2019.pdf

Hernández, M. (2019). La UNAM, institución con más patentes otorgadas por el IMPI. Gaceta UNAM, 6 de mayo. [Online] Available:

https://www.gaceta.unam.mx/la-unam-institucion-con-mas-patentes-otorgadas-por-el-impi/

IMPI. (2018). El IMPI en cifras: enero 1993- diciembre de 2018. [Online] Available: https://www.gob.mx/cms/uploads/attachment/file/441198/IMPI_en_CIFRAS_enero-diciembr e_2018_FINAL.pdf

Ismail, K., Omar, W. Z. W., \& Majid, I. A. (2011). The commercialisation process of patents by universities. African Journal of Business Management, 5(17), 7198-7208.

https://doi.org/10.5897/AJBM09.255

Loukil, K. (2019). Macroeconomic Determinants of Entrepreneurship in Emerging and 
Developing Countries. Business and Economic Research, 9(4), 79-88.

https://doi.org/10.5296/ber.v9i4.15713

Lazcano, A. (2019). Quo Vadis Mexican Science. Science, 365(6451), 301.

https://doi.org/10.1126/science.aay7980

Laurell, A. C. (2018). Sociedad Meritocrática. La Jornada, Opinión,16 agosto. [Online] Available: https://www.jornada.com.mx/2018/08/09/opinion/a03a1cie

Ledford, H. (2013). Universities struggle to make patents pay. Nature, 501(7468), 471-472. https://doi.org/10.1038/501471a

Link, A. N., Rothaermel, F. T., \& Siegel, D. S. (2008). University Technology Transfer: An Introduction to the Special Issue. IEEE Transactions on Engineering Management, 55(1), 5-7. https://doi.org/10.1109/TEM.2007.912811

Lockett, A., Wright, M., \& Franklin, S. (2003). Technology transfer and universities' spin-out strategies. Small Business Economics, 20(2), 185-200.

https://doi.org/10.1023/A:1022220216972

Martínez, C. (2006). El método de estudio de caso: estrategia metodológica de la investigación científica. Universidad del Norte Barranquilla, Colombia. Pensamiento \& Gestión, 20, 165-193. [Online] Available: https://www.redalyc.org/pdf/646/64602005.pdf

Meyer, C. B., (2001). A Case in Case Study Methodology. Field Methods, 13(4), 329-352. https://doi.org/10.1177/1525822X0101300402

Meyer, S. M., Krahmer, F., \& Schmoch, U. (1998). Science-Based Technologies: University-Industry Interactions in Four Fields. Research Policy, 27(8), 835-851.

https://doi.org/10.1016/S0048-7333(98)00094-8

Meyer, M., \& Tang, P. (2007). Exploring the "value" of academic patents: IP management practices in UK universities and their implications for Third-Stream indicators. Scientometrics, 70(2), 415-440. https://doi.org/10.1007/s11192-007-0210-9

OCDE. (2012). Innovación y Crecimiento: en busca de una frontera en movimiento. Vandana Chandra, Deniz Eröcal, Pier Carlo Padoan, Carlos A. Primo Braga, Editores., Foro Consultivo Científico y Tecnológico, A. C México.

Osiobe, E. U. (2019). A Literature Review of Human Capital and Economic Growth. Business and Economic Research, 9(4), 179-196. https://doi.org/10.5296/ber.v9i4.15713

Piñeiro, A., Rodríguez, M. C., \& Arzola, M. (2013). Public Policy Model for I\&D+i to lead and Coordinate the Regional Innovation System in support to SMI's, Case Study of Bolivar State, Venezuela. Journal of technology management \& innovation, 8(supl.1), 53-63.

https://doi.org/10.4067/S0718-27242013000300034

Pontaza, D. (2017). Tec. de Monterrey y UNAM con más patentes registradas. TecReview, junio 26. [Online] Available:

https://tecreview.tec.mx/tec-monterrey-unam-patentes-registradas 
Roesler, C., \& Broekel, T. (2017). The role of universities in a network of subsidized R\&D collaboration: The case of the biotechnology-industry in Germany. Review of Regional Research, 37(2), 135-160. https://doi.org/10.1007/s10037-017-0118-7

Rosenberg, N. (2010). Studies on Science and the Innovation Process. World Scientific. pp. 412.

Schmal, S. R., López, G. M. del S., \& Cabrales, G. F., (2006). El camino hacia la patentación en las Universidades. Ingeniare. Revista chilena de ingeniería, 14(3), 172-186.

https://doi.org/10.4067/S0718-33052006000200002

Secretaría de Economía. (2017). Conoce las instituciones educativas nacionales que más patentan en nuestro país, 24 de junio. [Online] Available:

https://www.gob.mx/se/articulos/conoce-las-instituciones-educativas-nacionales-que-mas-pat entan-en-nuestro-pais?idiom=es

Tellis, W. M. (1997). Introduction to Case Study. The Qualitative Report, 3(2), 1-14. https://doi.org/ 10.46743/2160-3715/1997.2024

Viana, L., Jabour, D., Ramirez, P., \& da Cruz, G. (2018). Patents Go to The Market? University-Industry Technology Transfer from a Brazilian Perspective. J. Technol. Manag. Innov, 13(3), 24-35. https://doi.org/10.4067/S0718-27242018000300024

Vega-González L. R., \& Hernández-Jardinez, I. J. (2018). The cost of patenting in México. Revista Médica del Hospital General de México, 81(3), 165-176.

https://doi.org/10.1016/j.hgmx.2017.05.004

Veugelers, R., \& Cassiman, B. (2005). R\&D cooperation between firms and universities. Some empirical evidence from Belgian manufacturing. International Journal of Industrial Organization, 23(5-6), 355-379. https://doi.org/10.1016/j.ijindorg.2005.01.008

Viettha, D. SS. (2019). Economic Growth: How Inflation and the Exchange Rate Work Through the Stock Market as a Mediating Variable. Business and Economic Research, 9(4), 197-209. https://doi.org/10.5296/ber.v9i4.15790

WIPO. (2019). World Intellectual Property Indicators 2019. World Intellectual Property Organization, Geneva, Switzerland. [Online] Available:

https://www.wipo.int/edocs/pubdocs/en/wipo_pub_941_2019.pdf

Woldenberg, J. (2019). ¿A costa de qué y de quiénes? El Universal, Opinión, 5 de mayo. [Online] Available: https://www.eluniversal.com.mx/articulo/jose-woldenberg/nacion/recortes

Zaldívar, C. A. B., \& O’Connor, M. L. (2012). Universidad, Patentes e Innovación. Revista Cubana de Ingeniería. 


\section{Copyright Disclaimer}

Copyright for this article is retained by the author(s), with first publication rights granted to the journal.

This is an open-access article distributed under the terms and conditions of the Creative Commons Attribution license (http://creativecommons.org/licenses/by/4.0/). 